\title{
Family reintegration of children and adolescents in foster care in Brazilian municipalities with different population sizes
}

Andrea M. Iannelli ${ }^{1}$

Simone Gonçalves Assis ${ }^{1}$

Liana Wernersbach Pinto ${ }^{1}$
${ }^{1}$ Centro Latino-Americano de Estudos de Violência e Saúde Jorge Careli, Escola Nacional de Saúde Pública, Fiocruz. Av. Brasil 4036, Manguinhos. 21040-361 Rio de Janeiro RJ Brasil. andreaiannelli2003@

yahoo.com.br

\begin{abstract}
The scope of this article is to present and analyze data from Brazilian foster care services for children / adolescents from the perspective of family reintegration. It also seeks to support the implementation of public policies in order to provide effective reintegration in accordance with the differing local contexts. It uses data from 1,157 municipalities that have foster care services. The methodology takes into account the data collection of 2,624 Brazilian centers and 36,929 children and adolescents in care. The growing number of children/adolescents in care is in line with the increase in population size: 8.4 per small city; 60 per large city and 602.4 per metropolis. With respect to care residence in a different municipality there are varying indices: $12.4 \%$ in metropolises and $33.6 \%$ in small cities, revealing the absence of centers close to family units in the smaller communities. Regarding the activities promoted together with families, it was seen that there are still units that do not perform any activities, which runs contrary to Brazilian law. It is clear that policies for the child/adolescent in foster care centers need to consider the capacity of the municipality in accordance with population size to implement support actions for families to assist in family reintegration.
\end{abstract}

Key words Family reintegration, Children, Adolescents, Shelter, Foster care 


\section{Introduction}

The preservation of family and community ties is one of the main aspects of foster care, based on the Federal Constitution ${ }^{1}$, on the National Statute of Children and Adolescents ${ }^{2}$, on the National Plan for the Promotion, Protection and Support for the Rights of Children and Adolescents to Life with Family and Community ${ }^{3}$, and on the Technical Guidelines: Foster Care of Children and Adolescents ${ }^{4}$ and Law of Adoption ${ }^{5}$. The preservation of family and community ties has been guiding the public policies for the last two decades, trying to diminish foster care practices, which takes the child or adolescent away from their family or community. The promotion of a life surrounded by family and community is a joint attribution of the SAIs and of the social assistance network, which includes the Judiciary Power, the Public Prosecution Services (MP), the Guardianship Councils (CT) and Guardianship Rights.

SAIs were created to children and adolescents with fragile or broken family ties, assuring them full protection. SAIs may be an institutional shelter, home-residence or shared homes. The protective measure to receive the child or adolescent in foster care is not only exceptional but temporary, which means that it makes efforts to return the child or adolescent to his or her original family ${ }^{6}$.

Many authors emphasize the losses resultant from family deprivation and institutionalization $^{7-9}$. The child or adolescent under foster care experiences a separation from the family core, which can result in several feelings like sadness, insecurity, rejection, hate and deep anguish ${ }^{10}$. Foster care practices are part of the history of children and adolescents exposed to poverty, violence and abandon in Brazil, and protection is the reason to confine them in foster care institutions ${ }^{11}$.

Children and adolescents placed at SAIs had their rights violated once they were abandoned, were under social or personal risk or were neglected by their parents or guardians. The lack of material resources of the family or guardian, the abandonment, domestic violence, chemical dependence, living in the streets and orphanhood are the most frequent reasons children and adolescents end up at foster care ${ }^{6}$. Thus, it is difficult to reinsert these children and adolescents back to their families due to episodes of threatening or violation of their rights ${ }^{12}$, becoming a great challenge to the relevant authorities.

Literature says little about family reintegration practices carried out by SAIs throughout cities in the country. Therefore, this article strives to better understand the family reintegration practices of children and adolescents found under Protective Measures and sheltered by SAIs throughout the 1,157 Brazilian cities studied, to support the implementation of public policies capable to provide a careful and efficient reintegration, according to the different population sizes.

\section{Methodology}

This article is based on a National Survey on Children and Adolescents held at 2,624 SAIs located in 1,157 cities (representing $20.8 \%$ of the total Brazilian cities), made by public or private agencies, located throughout 27 states. The study collected data from all 36,929 children and adolescents at foster care units. The research was conducted between 2009 and 2010 in the five regions of the country, with the support of the Ministry for Social Development and Fight Against Hunger $(\mathrm{MDS})^{13}$.

Due to the absence of a single national register that gathers the institutions that provide foster care (public and private) for children and adolescents in Brazil, the list of existing institutions used by the research was created from two sources: a) survey conducted by the MDS from March to April 2009 with municipal and state managers across the country, so they could report the existing foster care services for children and adolescents in their states and municipalities upon online completion of the SUASWeb network; b) national list provided by the National Council of Justice (CNJ). The research was then initiated with these lists and some changes were made along the process: addition of 121 new cities that started to receive funding from the MDS in 2010 and that did not appear in the previous lists; exclusion of cities that were duplicated in the initial list; withdrawal of services that no longer existed or no longer worked as SAIs; refusal of 15 foster care units to participate in the research; inclusion of SAI by validation carried out in the city with social care professionals. Although the long process of elaboration, this list may still be incomplete due to the difficulties to obtain data. However, this study highlights the fact that the research conducted is the larger and most accurate work carried out about this topic in the country, up to 2011.

It is noteworthy to mention that the state of Minas Gerais was not part of the data collec- 
tion for this research, once there was a reliable previous survey conducted in 2008 by the State Department for Social Development (SEDESE/ MG) through Fundação João Pinheiro. SEDESE provided all data from the state of Minas Gerais so it could be incorporated to the national survey analyzed by this article.

The manager of each SAI had to fill out a questionnaire on the services provided and a questionnaire for each child and adolescent sheltered under protection measure (0-17 years), based on data from their medical records and information provided by the technicians. This article provides data from both surveys: number of SAIs and children/adolescents assisted; addresses of parents or guardians of the children and adolescents (same city of the SAI or another city); existing family tie; existence of siblings and legal status.

The Foster Care Services analyzed in this article are broken down by cities, classified by population size: small sized I = cities with fewer than 20,000 inhabitants; small sized II = population between 20,000 and 49,999 inhabitants; midsized $=$ population between 50,000 and 99,999 inhabitants; large $=$ population between 100,000 and 899,999 inhabitants; metropolis = cities with 900,000 inhabitants or more. This study conducted bivariate analysis between the city size variable and the following variables: family residence location in relation to the city of the IAS; presence of family ties with the children and adolescents assisted by the services; existence and frequency of family visits; existence of siblings and their location (with the family or SAI); existing activities in the IAS that include families and the services offered to them and the legal status.

The research was authorized by the Research Ethics Committee of Escola Nacional de Saúde
Pública/FIOCRUZ, as well by the following entities: MDS, National Council of Justice; National Council for the Rights of Children and Adolescents and the National Council of Social Services, as well as by the State and Municipal Departments of Social Services. The managers of SAIs, the professionals of these services, members of the Network of Protection and Support for Children and Adolescents' Rights; and family members that were interviewed signed a consent form.

\section{Results}

Table 1 shows the distribution of SAIs and the number of children and adolescents in foster care, according to city size. The table also shows the progression of the number of SAIs and of children and adolescents sheltered as the population grows. The number of SAIs and of children and adolescents in foster care is quite lower in small sized cities than in large cities or metropolises. It is noteworthy that there are much more large sized cites than metropolises in the country, thus the reason that the first are predominant in the research on the number of SAIs and of children and adolescents sheltered. However, in the comparison of the number of children and adolescents sheltered at SAIs by city size, the number grows as the population size grows, reaching 60 per large city and 602.4 per metropolis.

Table 2 shows the family tie status of the children and adolescents in foster care. A significant part of the children and adolescent's families is present at the SAIs, regardless of the population size: data ranges between $47.3 \%$ in mid-sized cities and 58\% at metropolises. However, the percentage of children and adolescents without family ties is quite significant in all cit-

Table 1. Distribution of SAIs and of the number of children and adolescents sheltered, according to city size. Brazil, 2009-2010.

\begin{tabular}{|c|c|c|c|c|c|c|}
\hline \multirow[t]{2}{*}{ City Size } & \multirow{2}{*}{$\begin{array}{c}\text { Cities } \\
\mathrm{N}\end{array}$} & \multicolumn{2}{|c|}{ SAI } & \multicolumn{2}{|c|}{ Children/adolescents } & \multirow{2}{*}{$\begin{array}{c}\text { \# of ones sheltered } \\
\text { per city - rate }\end{array}$} \\
\hline & & $\mathbf{N}$ & $\%$ & $\mathbf{N}$ & $\%$ & \\
\hline Small size I & 340 & 351 & 13.4 & 2.860 & 7.8 & 8.4 \\
\hline Small size II & 367 & 458 & 17.5 & 5.378 & 14.6 & 14.7 \\
\hline Mid-sized & 202 & 317 & 12.1 & 4.475 & 12.2 & 22.2 \\
\hline Large size & 231 & 865 & 33.1 & 13.849 & 37.6 & 60.0 \\
\hline Metropolis & 17 & 626 & 23.9 & 10.240 & 27.8 & 602.4 \\
\hline Total & 1.157 & $2.617^{*}$ & 100.0 & 36.802 & 100.0 & 31.8 \\
\hline
\end{tabular}

* Data on size not available for seven SAIs and 127 children and adolescents in the State of Minas Gerais. 
ies (between $19.4 \%$ in small sized II and $22 \%$ in large size ones). It is important to mention that the percentage of children and adolescents with missing or not localized family is higher in the metropolises (3.4\%). Moreover, the table shows that the larger the population size, the higher is the percentage of children/adolescents under legal restraint to have contact with their families.

Table 3 shows the place of residence of the parents and guardians, according to SAIs locations. There are more families of children and adolescents living in the same city, mostly in large cities and metropolises. Still, the table shows the high percentage of children and adolescents whose parents live in different cities than the ones they are located, ranging from $12.4 \%$ in the metropolises to $33.6 \%$ in small cities (I).

Table 4 shows that $76.1 \%$ of children and adolescents living at SAIs have information about the existence of siblings in their medical records, regardless of the size of the city. The number of siblings living in other foster care units is high (mid-sized is $19.3 \%$ and large size $34.7 \%$ ).

Table 5 describes the activities developed by the SAIs with the families, according to data obtained from the managers. The table shows the need of prioritizing the integration of siblings in the same foster care unit, to schedule visits at pre-established days and times and to include professionals to participate in the visits $(80 \%$ in cities of different population sizes, with slight rise in larger cities). Moreover, less than $6 \%$ of the foster care units (regardless of population size) do not conduct any activity with the families, despite the guidelines and regulations in force in the country. In addition to the activities mentioned in Table 5, the managers were asked about what services were offered to the families. Thus, in general, the smaller cities offer fewer activities to the families than the larger ones.

Concerning the legal status of the 32,621 children and adolescents (excluding the state

Table 2. Family tie ${ }^{*}$ status of children/adolescents sheltered at SAIs, according to city size. Brazil, 2009-2010 $(\mathrm{N}=36.802)$.

\begin{tabular}{|c|c|c|c|c|c|c|c|c|c|c|c|c|c|c|}
\hline \multirow[t]{2}{*}{ Population Size } & \multicolumn{2}{|c|}{$\begin{array}{l}\text { With family } \\
\text { and with tie }\end{array}$} & \multicolumn{2}{|c|}{$\begin{array}{c}\text { With family } \\
\text { and without } \\
\text { tie }\end{array}$} & \multicolumn{2}{|c|}{$\begin{array}{l}\text { With family } \\
\text { and no } \\
\text { information } \\
\text { about ties }\end{array}$} & \multicolumn{2}{|c|}{$\begin{array}{l}\text { With missing } \\
\text { or not } \\
\text { localized } \\
\text { family }\end{array}$} & \multicolumn{2}{|c|}{$\begin{array}{l}\text { With judicial } \\
\text { estoppel } \\
\text { contact with } \\
\text { family }\end{array}$} & \multicolumn{2}{|c|}{$\begin{array}{c}\text { No family } \\
\text { (orphan) }\end{array}$} & \multicolumn{2}{|c|}{$\begin{array}{c}\text { Do not } \\
\text { know }\end{array}$} \\
\hline & $\mathbf{N}$ & $\%$ & $\mathbf{N}$ & $\%$ & $\mathbf{N}$ & $\%$ & $\mathbf{N}$ & $\%$ & $\mathbf{N}$ & $\%$ & $\mathbf{N}$ & $\%$ & $\mathbf{N}$ & $\%$ \\
\hline Small size I & 1.600 & 55.9 & 600 & 21.0 & 32 & 1.1 & 23 & 0.8 & 141 & 4.9 & 21 & 0.7 & 443 & 15.5 \\
\hline Small size II & 2.637 & 49.0 & 1.044 & 19.4 & 81 & 1.5 & 87 & 1.6 & 342 & 6.4 & 61 & 1.1 & 1.126 & 20.9 \\
\hline Mid-sized & 2.117 & 47.3 & 948 & 21.2 & 38 & 0.8 & 57 & 1.3 & 295 & 6.6 & 23 & 0.5 & 997 & 22.3 \\
\hline Large size & 7.580 & 54.7 & 3.044 & 22.0 & 186 & 1.3 & 282 & 2.0 & 1.016 & 7.3 & 137 & 1.0 & 1.604 & 11.6 \\
\hline Metropolis & 5.950 & 58.1 & 1.925 & 18.8 & 117 & 1.1 & 350 & 3.4 & 1.018 & 9.9 & 117 & 1.1 & 763 & 7.5 \\
\hline Total & 19.884 & 54.0 & 7.561 & 20.6 & 454 & 1.2 & 799 & 2.2 & 2.812 & 7.6 & 359 & 1.0 & 4.933 & 13.4 \\
\hline
\end{tabular}

Table 3. Place of residence of the family of children/adolescents sheltered at SAIs ${ }^{*}$, according to city size. Brazil, 2009-2010 $(\mathrm{N}=30.718)$.

\begin{tabular}{|c|c|c|c|c|}
\hline \multirow{2}{*}{ Population Size } & \multicolumn{2}{|c|}{ Place of residence in the same city of SAI } & \multicolumn{2}{|c|}{ Place of residence in other city of SAI } \\
\hline & $\mathbf{N}$ & $\%$ & $\mathrm{~N}$ & $\%$ \\
\hline Small size I & 1.585 & 66.4 & 803 & 33.6 \\
\hline Small size II & 2.864 & 69.2 & 1.277 & 30.8 \\
\hline Mid-sized & 2.542 & 75.5 & 824 & 24.5 \\
\hline Large size & 9.476 & 80.4 & 2.312 & 19.6 \\
\hline Metropolis & 7.916 & 87.6 & 1.119 & 12.4 \\
\hline Total & 24.383 & 79.4 & 6.335 & 20.6 \\
\hline
\end{tabular}

${ }^{*}$ Foster care services 
Table 4. Status of the siblings of the children/adolescents sheltered at SAIs, according to city size. Brazil, 2009$2010\left(\mathrm{~N}=38.618^{*}\right)$.

\begin{tabular}{|c|c|c|c|c|c|c|c|c|c|c|}
\hline \multirow{3}{*}{ Size } & \multicolumn{10}{|c|}{ Status of siblings } \\
\hline & \multicolumn{2}{|c|}{$\begin{array}{l}\text { Living with family } \\
\text { of origin (nuclear/ } \\
\text { extensive) }\end{array}$} & \multicolumn{2}{|c|}{$\begin{array}{l}\text { Sheltered } \\
\text { at the } \\
\text { same unit }\end{array}$} & \multicolumn{2}{|c|}{$\begin{array}{c}\text { Sheltered at } \\
\text { other foster } \\
\text { care units }\end{array}$} & \multicolumn{2}{|c|}{$\begin{array}{l}\text { Adopted } \\
\text { by other } \\
\text { families }\end{array}$} & \multicolumn{2}{|c|}{ N/A } \\
\hline & $\mathbf{N}$ & $\%$ & $\mathbf{N}$ & $\%$ & $\mathbf{N}$ & $\%$ & $\mathbf{N}$ & $\%$ & $\mathbf{N}$ & $\%$ \\
\hline Small size I & 1.076 & 62.6 & 1.533 & 70.3 & 132 & 16.8 & 217 & 25.0 & 75 & 10.3 \\
\hline Small size II & 1.776 & 53.1 & 2.593 & 62.2 & 321 & 16.9 & 365 & 18.7 & 156 & 9.0 \\
\hline Mid-sized & 1.491 & 52.6 & 2.152 & 61.5 & 324 & 19.3 & 312 & 18.8 & 100 & 6.9 \\
\hline Large size & 5.480 & 64.5 & 6.706 & 68.8 & 1.621 & 34.7 & 1.027 & 25.2 & 392 & 11.4 \\
\hline Metropolis & 4.000 & 64.2 & 4.938 & 68.7 & 989 & 30.6 & 471 & 17.3 & 371 & 14.2 \\
\hline
\end{tabular}

${ }^{*}$ May have multiple answer.

Table 5. Activities promoted by SAIs to stimulate and strength the tie with the families of origin $\left(\mathrm{N}=13,881^{*}\right)$.

\begin{tabular}{|c|c|c|c|c|c|c|c|c|c|c|}
\hline \multirow{3}{*}{ Actions } & \multicolumn{10}{|c|}{ City Size } \\
\hline & \multicolumn{2}{|c|}{$\begin{array}{l}\text { Small } \\
\text { size I }\end{array}$} & \multicolumn{2}{|c|}{$\begin{array}{l}\text { Small } \\
\text { size II }\end{array}$} & \multicolumn{2}{|c|}{ Mid-sized } & \multicolumn{2}{|c|}{$\begin{array}{l}\text { Large } \\
\text { size }\end{array}$} & \multicolumn{2}{|c|}{ Metropolis } \\
\hline & $\mathbf{N}$ & $\%$ & $\mathbf{N}$ & $\%$ & $\mathbf{N}$ & $\%$ & $\mathbf{N}$ & $\%$ & $\mathbf{N}$ & $\%$ \\
\hline Gives priority to the integration of siblings & 297 & 84.6 & 378 & 82.5 & 285 & 89.9 & 765 & 88.4 & 531 & 84.8 \\
\hline $\begin{array}{l}\text { Give advices to professionals to be in } \\
\text { contact with the families during the visits }\end{array}$ & 229 & 73.9 & 285 & 77.0 & 212 & 82.2 & 625 & 80.7 & 446 & 78.7 \\
\hline $\begin{array}{l}\text { Schedule family visits in pre-established } \\
\text { days/date }\end{array}$ & 268 & 77.5 & 341 & 78.9 & 256 & 84.2 & 724 & 85.2 & 511 & 83.5 \\
\hline Incentive to phone contact/mail exchange & 188 & 53.6 & 251 & 54.8 & 186 & 58.7 & 613 & 70.9 & 478 & 76.4 \\
\hline $\begin{array}{l}\text { Promotes visit of children/adolescents to } \\
\text { their homes }\end{array}$ & 168 & 54.2 & 204 & 55.0 & 167 & 64.5 & 554 & 71.6 & 422 & 74.3 \\
\hline $\begin{array}{l}\text { Carry out special dates celebrations at the } \\
\text { unit with the presence of the family of } \\
\text { origin }\end{array}$ & 149 & 47.9 & 202 & 54.3 & 156 & 60.2 & 539 & 68.8 & 421 & 73.9 \\
\hline $\begin{array}{l}\text { Promotes involvement of the family of } \\
\text { origin on the follow-up of the children/ } \\
\text { adolescent's health and school life }\end{array}$ & 151 & 48.6 & 187 & 50.5 & 151 & 58.5 & 490 & 63.3 & 380 & 67.0 \\
\hline $\begin{array}{l}\text { Promotes outdoor leisure time of } \\
\text { children/adolescents with their families }\end{array}$ & 87 & 24.8 & 134 & 29.3 & 87 & 27.4 & 265 & 30.6 & 255 & 40.7 \\
\hline $\begin{array}{l}\text { Provides aid to transportation so the } \\
\text { families can visit the unit. }\end{array}$ & 71 & 22.9 & 79 & 21.4 & 66 & 25.6 & 255 & 32.9 & 262 & 46.2 \\
\hline $\begin{array}{l}\text { Do not carry out incentive actions for the } \\
\text { child/adolescent to live with their families } \\
\text { of origin }\end{array}$ & 11 & 3.1 & 24 & 5.4 & 7 & 2.2 & 34 & 4.0 & 34 & 5.5 \\
\hline
\end{tabular}

"May have multiple answer.

of Minas Gerais), $46.4 \%(15,148)$ of them are being prepared for reintegration or to return to their families or guardians. This reality is similar according to the population size, ranging from $44.2 \%$ in small sized II cities and $47 \%$ in large sized ones.
Other legal status observed: $9.9 \%$ of children and adolescents are under paternal power suspension; $11.1 \%$ with paternal power destitution in procedure action; $2.7 \%$ in procedure action process of custody/guardianship; and $18.3 \%$ of the cases have no information in the medical 
records. Such data are quite similar in cities of different population sizes.

\section{Discussion}

There is a growth trend in the country of SAIs and of children and adolescents under foster care as the city size increases, according to the reasoning that the offer is higher in larger urban centers ${ }^{14}$. Thus, assuming that there is more agility in the family visits and more attempts to family reintegration. However, the long distances of larger cities and the high prices of public transportation may hinder the access of families to the foster care units. A study that evaluated 7,807 children in the state of Florida, USA, pointed out that the geographical location of the child's home determined a higher or lower possibility to leave foster care. Urban areas in Florida had the lowest release rates of children from the institutions. The authors associate that administrative rules lead to different periods of staying, as well as involvement strategies of the staff with the families. Other aspects that affect the sheltering concern mental health issues (due to disorders resultant from the use of psychoactive substance and psychiatric problems of parents and children $)^{15}$. Glisson et al. ${ }^{16}$ found out that children from urban areas were more likely to leave state custody than children from rural regions in the US. These aspects show the need for further research on the topic, identifying which factors may explain the existing variations. It is noteworthy that there is a significant gap in national studies that addresses such issues.

Another important aspect concerns the difficulty of ascertaining the actual number of SAIs and of children and adolescents under this service in Brazil, as well as the existing dynamism in the area, making it difficult to obtain a single national register. The national survey on foster care conducted by IPEA $^{6}$ found 20,000 children and adolescents in 626 institutions. This present survey (2009-2010) ${ }^{13}$ identified 36,929 children and adolescents in 2624 foster care units. Data from the Social Assistance System Survey conducted in 2012 found 2,380 foster care units and 33,456 children and adolescents. On the other hand, the National Register of Children and Adolescents in Foster Care of the National Council of the Public Prosecution Services reports 4,029 foster care units hosting 43,585 children and adolescents ${ }^{17}$.

The foster care units must urgently create interconnected databases and constantly update them, resulting in more effective public policies.
Concerning the family tie status of children and adolescents sheltered at SAIs, it is important to mention that in the metropolises studied, the number of missing and not located families, as well as of children and adolescents under family contact legal constraint is high, in comparison to smaller cities. More populous cities implylonger distances among Judiciary Power, SAIs, individuals, and their families. It is necessary to find the reasons that drove the child and adolescent to foster care, as well as to investigate the personal and family issues that resulted to carry out the family reintegration with safety ${ }^{18,19}$.

Family reintegration is not a simple and agile task; the family of this child and adolescent may be facing difficulties and may be under risk ${ }^{20,21}$. Children and adolescents leave the SAIs and return home not always under favorable circumstances, once the conditions that once restrained them to live with their families may still exist ${ }^{22}$.

Thus, it is important to mention that the need to comply with legal regulations (maximum of two years in foster care) can result in a family reintegration without the proper preparation, without solving the problems that sent the child or adolescent to foster care, contributing to reoccurrences.

Relevant rates are found in all sizes of cities in what concerns the place of residence of the parents/guardians of children and adolescents. This happens when there is no foster care service in the family's city of residence, or the parents work in different and distant cities from where they live, or they find it difficult to access the foster care unit location. These facts hinder family reintegration and favor permanence of children and adolescents in foster care services. Thus, there is a need to implement the municipalization of the service, as recommended by the Brazilian Statute of Children and Adolescents (ECA - Section 88 paragraph I $)^{2}$. The National Plan for the Promotion, Protection and Support of the Right of Children and Adolescents to Life with Family and Community ${ }^{3}$ establishes that public facilities and services must be available in sufficient quantity and quality, considering regional, state, and municipal characteristics regarding the size, geography and population density, and culture, striving to strengthen family ties.

A survey conducted in 2008 in the city of Rio Grande identified that $100 \%$ of children and adolescents living in SAIs demonstrated dissatisfaction and suffering in their daily lives due to the absence of the family. The lack of a municipal 
SAI was confirmed by $40 \%$ of the professionals; another $40 \%$ reported the existence of a non-municipal program, and $20 \%$ said that there are initiatives from the executive power ${ }^{23}$. This finding shows the lack of municipal commitment to implement programs aimed at assisting families of those at foster care units, and the need to demand more articulation of the social assistance network.

There is a quite considerable number of siblings of children and adolescents being placed in different SAIs or foster care units in all city sizes, with an emphasis on large cities and metropolis. This fact points to difficulties in the implementation of Section 92 of $\mathrm{ECA}^{2}$, which states that a group of siblings must not be separated. Weber ${ }^{24}$ reports that $60 \%$ of the existing SAIs in the city of Rio Grande host children and/or adolescents separated by gender. Only $20 \%$ of SAIs managers find it important to have both genders together, while most of them $(80 \%)$ do not agree in case of adolescents, once it is a phase of discovery of sexuality. This view implies the separation of siblings of different genders, which can be considered a form of neglect, due to the lack of facilities to meet the population or due to disarticulation of the social assistance network, which is not organized to avoid this situation.

Regarding the activities promoted by the SAIs to stimulate and strengthen the bond with the families, there are units $(\mathrm{N}=110)$ that do not carry out any activities with them, not complying with laws and standards related to childhood and youth in Brazil. In general, regardless of the city size, many SAIs still do not encourage activities with the family of origin, showing a lack of inspection by the relevant authorities, such as the Judiciary Power, Public Prosecution Services and Child Protection Board.

The IPEA ${ }^{6}$ conducted a research and found to be adequate the services: (i) that give incentive to activities with the family of origin; and (ii) that keep siblings together. That is, only $6.6 \%$ meet these criteria. The other activities developed with the families include: (i) visits to the child or adolescent's residence; (ii) social follow-up; (iii) support meetings or groups; and (iv) insertion in protection/family support programs. Only $14.1 \%$ of the SAIs meet this criteria. The data reported point out non-compliance with laws and regulations: "every effort should be made to preserve and strengthen family and community ties of children and adolescents in foster care services. Such ties are critical at this stage of human development, as it provides the child and adolescent conditions for a healthy development that favors the formation of their identity and construction and an individual and citizen" ${ }^{\prime 3}$.

SAIs are accountable for taking care of family and community ties, striving to keep or reestablish them. However, SAIs not always efficiently meet family reintegration tasks: "although it is an ECA's executing agency, in many respects, the foster care unit contradicts its precepts ... The institutional organization creates obstacles for families to not "disturb the work"

Once it should keep the bond, the institution's work is indeed to open space to the family, and not to constrain them to two hours of weekly visits" ${ }^{25}$. Many SAIs report they do not have resources to carry out a family reintegration, doing so in a precarious manner, leaving it to the Judiciary staff, which also performs it insufficiently ${ }^{26}$. The work provided by the technical staff of the foster services has been considered critical to increase family reunification rates in other countries $^{27}$, from actions such as gestures, words and attitudes by all those involved: children, adolescents, families and SAIs ${ }^{8,19,23}$.

Problems related to the structure, organization and functioning of the families also interfere in the returning of the child or adolescent to their homes. A study conducted by Silva e Nunes ${ }^{28}$ points out that after returning home, the child or adolescent are exposed to the social vulnerabilities experienced by their families, such as social-related problems. Thus, an effective family reintegration demands a careful evaluation of the family's life condition (socioeconomic); how strong is the willingness of the family to have the child or adolescent back ; and the bond among them $^{8}$. The fragility in the family reintegration process occurs, according to Siqueira ${ }^{12}$, from the monitoring and evaluation by the foster care services and from the existing vulnerabilities in the families.

Another aspect that encourages family reintegration refers to the support provided by social programs that support the families of these children and adolescents, strengthening the reintegration $^{29,30}$. However, the foster care services fails to offer the child or adolescent the affectional bond they need to further develop. The psychological health of these children and adolescents depends, above all, on the environment they experience in these shelters ${ }^{31}$. The foster care unit does not represent only a daily care space, but a place opened to family-related activities. This is what makes it different from other modalities of service, turning it even more complex ${ }^{32}$. Finally, this study highlights the constraints identified, 
such as the lack of studies, especially those addressing how SAIs carry out activities involving family reintegration of children and adolescents in different regions of the country, and the difficulty to obtain reliable statistics on institutional care from the states.

\section{Final Remarks}

The policies designated for foster care of children and adolescents need to take into account the population size to articulate actions to support families, corroborating to the family reintegration. Families can fully play their roles when they benefit from rights such as access to health, education and work.

The restructuring of a family demands subsidies from the local administration (together with the civil society, state, and federation) to address the serious social issues such as unemployment, addiction to alcohol and drugs, domestic violence, among others.

The qualification of the professionals working in SAIs and of the entire social assistance network to better assist those who arrive at the foster care units, and the existing structural conditions of these services are proximal links that need to be improved to diminish the time spent in these institutions.

In conclusion, family reintegration of institutionalized children and adolescents requires trained professionals that must work carefully, and an efficient network of social support, with public programs that provide assistance and protection to families, with the goal to empower them to overcome their social vulnerabilities. These needs are clearly identified in the cities studied, in greater or lesser need, depending on the population size. 


\section{Collaborations}

AM Iannelli, SG Assis e LW Pinto participated equally in all stages of preparation of the article.

\section{References}

1. Constituição da República Federativa do Brasil: promulgada em 05 out.1988. Organização dos textos, notas remissivas e índices por Juarez de Oliveira. $11^{\text {a }}$ ed. atual e ampliada. São Paulo: Saraiva; 1995.

2. Brasil. Estatuto da Criança e do Adolescente. Lei $n^{\circ}$ 8.069, de 13/07/1990: Constituição e Legislação relacionada. São Paulo: Cortez; 1991.

3. Brasil. Ministério do Desenvolvimento Social e Combate à Fome. Plano Nacional de Promoção, Proteção e Defesa do Direito de Crianças e Adolescentes à Convivência Familiar e Comunitária. Brasília: CNAS; 2006. [acessado 2013 mar 11]. Disponível em: http://www. mp.rs.gov.br/areas/infancia/arquivos/planonacional. pdf

4. Conselho Nacional Dos Direitos Da Criança e Do Adolescente (Conanda). Conselho Nacional de Assistência Social (CNAS). Orientações Técnicas para os Serviços de Acolhimento para Crianças e Adolescentes. Brasília: Conanda, CNAS; 2008.

5. Brasil. Lei no 12.010/09, de 3 de agosto de 2009. Dispõe sobre adoção; altera as Leis nos 8.069, de 13 de julho de 1990 - Estatuto da Criança e do Adolescente, 8.560, de 29 de dezembro de 1992; revoga dispositivos da Lei no 10.406, de 10 de janeiro de 2002 - Código Civil, e da Consolidação das Leis do Trabalho - CLT, aprovada pelo Decreto-Lei no 5.452, de 1 de maio de 1943; e dá outras providências. Diário Oficial da União 2009; 4 ago.

6. Silva ERA, Aquino LMC. Os abrigos para crianças e adolescentes e o direito à convivência familiar e comunitária. Rio de Janeiro: IPEA; 2005. [acessado 2013 mar 9]. Disponível em: http://www.ipea.gov.br/agencia/images/ stories/PDFs/politicas_sociais/ENSAIO3_Enid11.pdf

7. Spitz RA. O primeiro ano de vida: um estudo psicanalítico do desenvolvimento normal e anômalo das relaçães objetais. São Paulo: Martins Fontes; 1979.

8. Bowlby J. Formação e Rompimento dos laços afetivos. São Paulo: Martins Fontes; 1997.

9. Winnicott DW. A criança desapossada e como pode ser compensada pela falta de vida familiar. In: Winnicott DW. Privação e delinquência. São Paulo: Martins Fontes; 1999. p. 195-213.

10. Careta DS. Análise do desenvolvimento emocional de gêmeos abrigados no primeiro ano de vida: encontros e divergências sob a perspectiva winnicottiana [dissertação]. São Paulo: Universidade de São Paulo; 2006.

11. Rizzini I. A institucionalização de crianças no Brasil. Rio de Janeiro: Ed. PUC-RJ; 2004

12. Siqueira AC. Crianças, adolescentes e transições ecológicas: Instituições de abrigo e família como contextos de desenvolvimento [tese]. Porto Alegre: Universidade Federal do Rio Grande do Sul; 2009.

13. Assis SG, Farias LOP. Levantamento Nacional de Crianças e Adolescentes em Acolhimento Institucional e Familiar. São Paulo: Hucitec; 2013.

14. Castells M, Borja J. "As cidades como atores políticos". Novos Estudos CEBRAP 1996; 45(julho):152-166. [acessado 2013 out 26]. Disponível em: http://www.acsmce. com.br/wp-content/uploads/2012/10/AS-CIDADESCOMO-ATORES-POL\%C3\%8DTICOS.pdf 
15. Becker MA, Jordan N, Larsen R. Predictors of successful permanency planning and length of stay in foster care: The role of race, diagnosis and place of residence. Children and Youth Services Review 2007; (29):11021113.

16. Glisson C, Bailey JW, Post JA. Predicting the time children spend in state custody. Social Service Review 2000; 74(2):253-280.

17. Conselho Nacional do Ministério Público. Ação integrada. CNMP, CNJ e MDS estudam a unificação de dados sobre abrigos para crianças e adolescentes. [acessado 2013 mar 11]. Disponível em: http://www. cnmp.gov.br/portal/index.php?option $=$ com_conten$\mathrm{t} \&$ view $=$ article\&id $=1834$ :acao-integrada\&Itemid $=146$

18. Siqueira AC, Dell'aglio DD. O impacto da institucionalização na infância e na adolescência: Uma revisão da literatura. Psicologia e Sociedade 2006; 18:71-80.

19. Azôr AMGCCV, Vectore C. Abrigar/desabrigar: conhecendo o papel das famílias nesse processo. Estudos de Psicologia 2008; 25:77-89.

20. Dozier M1, Stovall KC, Albus KE, Bates B. Attachment for infants in foster care: The role of caregiver state mind. Child Dev 2001; 72(5):1467-1477.

21. Zeanah HC, Smyke AT, Koga SF, Carlson E; Bucharest Early Intervention Project Core Group. Attachment in institutionalized and community in Romania. Child Dev 2005; 76(5):1015-1028.

22. Vasconcelos QA, Yunes MAM, Garcia NM. Um estudo ecológico sobre as interações da família com o abrigo. Paidéia 2009; 19(43):221-229.

23. Borba RCA. A institucionalização de crianças e adolescentes e o direito à convivência familiar e comunitária: um panorama da cidade do Rio Grande. In: Anais $17^{\circ}$ Congresso de iniciação científica e $10^{\circ}$ Encontro de pós-graduação; 2008. Pelotas: UFPel. [acessado 2013 fev 25]. Disponível em: http://www.ufpel.edu.br/ cic/2008/cd/pages/pdf/CH/CH_00864.pdf

24. Weber LND. Os filhos de ninguém - abandono e institucionalização de crianças no Brasil. Revista Conjuntura Social 20004; jul:30-36. [acessado 2013 fev 25]. Disponível em: http://www.lidiaweber.com.br/Artigos /2000/2000Osfilhosdeninguem.pdf.
25. Oliva PP. O Desvendamento do real numa instituição de abrigo para crianças e adolescentes. Revista Virtual Textos e Contextos 2004; 3(1):1-13.

26. Nascimento ML, Lacaz AS, Travassos M. Descompassos entre a lei e o cotidiano nos abrigos: percursos do ECA. Aletheia 31, abr. 2010. [acessado 2013 fev 26]. Disponível em: http://pepsic.bv salud. org/scielo.php?script= sci_arttext\&pid=S1413-03942010000100003\&lng=pt \&nrm=iso

27. Lewandowski CA, Pierce L. Does family-centered out -of-home care. work? comparison of a family-centered approach and traditional care. Social Work Research 2004; 28(3):143-151.

28. Silva MRS, Nunes KS. Avaliação e diagnóstico do processo de reinserção familiar e social de crianças e adolescentes egressos de uma casa de passagem. Cogitare Enfermagem 2004; 9(1):42-49.

29. Courtney ME. Reentry to foster care of children returned to their families. Social Service Review 1995; 69(2):226-241.

30. Festinger T. Going home and returning to foster care. Children and Youth Services Review 1996; 18(4/5):383402.

31. Barros RC, Fiamenghi Junior GA. Interações afetivas de crianças abrigadas: um estudo etnográfico. Cien Saude Colet 2007; 12(5):1267-1276.

32. Cavalcante LIC, Magalhães CMC, Pontes FAR. Processos de saúde e doença entre crianças institucionalizadas: uma visão ecológica. Cien Saude Colet 2009; 14(2):615-662.

Article submitted 16/10/2013

Approved 11/12/2013

Final version submitted 19/12/2013

Errata 20(1):39-48

\section{p. 39, which reads:}

Liana Wenersbach Pinto ${ }^{1}$

reads up:

Liana Wernersbach Pinto ${ }^{1}$ 